Niepełnosprawność. Dyskursy pedagogiki specjalnej

\title{
Grażyna Gunia
}

Uniwersytet Pedagogiczny w Krakowie

\section{Gotowość studentów do komunikacji alternatywnej $\mathrm{w}$ działaniach edukacyjno-terapeutycznych z osobą z zaburzeniami mowy fonicznej}

Przedmiotem rozważań artykułu jest komunikacja wspomagająca i alternatywna oraz jej znaczenie w działaniach edukacyjno-terapeutycznych z osobą z zaburzeniami mowy fonicznej. Całość opracowania podzielono na dwie części. W pierwszej części omówiono główne założenia teoretyczne na temat porozumiewania się bez słów z perspektywy pedagogiki specjalnej i logopedii. W drugiej części tekstu przedstawiono wyniki z badań własnych i próbę odpowiedzi na pytanie: Jak studenci pedagogiki specjalnej percypują pomoc w przezwyciężaniu barier komunikacyjnych osób z niepełnosprawnością?

Słowa kluczowe: gotowość nauczycieli, komunikacja alternatywna i wspomagająca, osoby z zaburzeniami komunikacji

\section{Students' willingness to augmentative and alternative communication in educational and therapeutic activities with a person with speech disorders}

The subject of the study is supportive and alternative communication and its importance in educational and therapeutic activities with a person with speech disorders. The article is divided into two parts. The first part discusses the main theoretical assumptions about non-verbal communication from the perspective of special education and speech therapy. In the second part of the text is devoted to presentation of the results of our own research which eventually attempts to answer the question: how do special education students perceive help in overcoming the communication barriers of people with disabilities?

Keywords: teacher readiness, augmentative and alternative communication, persons with communication disorders 


\section{Wprowadzenie}

Poszukiwanie wspólnego systemu językowego w sytuacji komunikacyjnej, w jakiej znajdują się osoby, które nie mówią od urodzenia lub utraciły zdolność porozumiewania się za pomocą mowy artykułowanej, jest problemem wielu osób. Zrozumienie tych osób, które nie mówią, lub mówią w taki sposób, że ich nie rozumiemy, a chcą się komunikować, jest poszukiwaniem słów, znaków, symboli, czyli poszukiwaniem pomocy $\mathrm{w}$ realizacji zamierzenia komunikacyjnego i w pokonywaniu barier społecznych. Jak pomóc osobom, które posługują się, innym od mowy, systemem językowym, którego nie znamy? Co robić w nowej nieznanej sytuacji komunikacyjnej, by nie być zdziwionym, bezradnym w rozumieniu komunikatów tworzonych i przekazywanych w zróżnicowanych systemach językowych? Czy przeobrażenia postaw wobec osób niepełnosprawnych, jak i zmiany w przestrzeni komunikacyjnej wokół osób, które nie mówią, ale komunikują się za pomocą alternatywnych sposobów, ułatwiają gotowość do przekraczania granic językowych?

Próba odpowiedzi na wymienione pytania oraz dwa wydarzenia szeroko komentowane w mediach ogólnopolskich były inspiracją do rozważań na temat roli komunikacji alternatywnej i wspomagającej w kontekście zmian w studiach nad niepełnosprawnością.

Pierwsze wydarzenie związane jest z osobą krakowskiego aktora Krzysztofa Globisza, który w 2014 roku przeszedł udar mózgu. Pomimo zaburzenia mowy w postaci afazji, niedowładu prawej części ciała i słów lekarzy, „że żadnego Globisza tam nie ma. Że to tylko ciało", aktor powrócił do wykonywania swojego macierzystego zawodu na scenie Narodowego Starego Teatru w Krakowie [Gazur 2016]. Było to możliwe dzięki determinacji i pomocy wielu ludzi - rodziny, znajomych i terapeutów. Chociaż aktor miał trudności z poruszaniem się i prawie nie mówił, to zagrał "bez słów”, bo jak twierdzi reżyser Paweł Miśkiewicz [Gazur 2016, s. C04', „Aktor czasem nie musi wypowiadać słów. Gra aktorska to korzystanie z całego wachlarza umiejętności, głos jest tylko jednym z nich. Ale talent przebija się nawet przez niezdolność mówienia. I Krzysztof Globisz znajduje środki, by wyrazić się na scenie, nawet gdy nic nie mówi". Kolejny spektakl w Teatrze Łaźnia Nowa: „Wieloryb The Globe" (premiera odbyła się 9 grudnia 2016 r.), w którym gra K Globisz, jest sztuką o poszukiwaniu wspólnego języka w nowej nieznanej sytuacji komunikacyjnej, w jakiej znajdują się osoby, które utraciły zdolność porozumiewania się za pomocą mowy fonicznej. Wieloryb $w$ naturalnym środowisku jest postrzegany jako zręczne, pełne wdzięku, zwierzę, ale sceniczne zwierzę jest uosobieniem osoby zagrożonej, bezradnej, oczekującej pomocy. Widzowie spektaklu, tak jak pedagodzy specjalni, zastanawiają się jaką formę pomocy wybrać? 
Drugie wydarzenie to występ w programie telewizyjnym „Taniec z gwiazdami" Miss Świata Głuchych z 2016 roku, ambasadorki społeczności osób Głuchych - Iwony Cichosz. Występ osoby z niepełnosprawnością słuchową, która bez aparatów słuchowych nie słyszy od urodzenia, ale mówi, przy czym w porozumiewaniu się preferuje alternatywny język - migowy - ukazał widzom, że brak słuchu nie jest przeszkodą w tańcu, a język migowy, tak jak każdy inny system językowy, wyraża myśli i emocje. Aplauz widzów programu, w systemie migowego bicia brawa, jest formą przybliżenia kultury językowej osób Głuchych i próbą zrozumienia idiosynkratycznych symboli komunikacji, które czasem odbierane są jako niewłaściwe zachowania, wręcz niekulturalne.

Symbolika historii wieloryba wyrzuconego na plażę oraz niesłyszącej tancerki, która posługuje się językiem migowym, innym od języka większości, są odzwierciedleniem sytuacji ludzi, których zamierzenia komunikacyjne nie są zawsze rozumiane przez odbiorcę lub są rozumiane dzięki tłumaczom. Jest to również przykład przedstawiania $\mathrm{w}$ mediach zróżnicowanych przestrzeni komunikacyjnych i kulturowych ludzi, wśród których żyjemy, a niektórzy z nich potrzebują pomocy, tak jak wieloryb zagrożony w określonej sytuacji. Człowiek $\mathrm{z}$ trudnościami lub zaburzeniami komunikacyjnymi czuje się zagrożony, wątpi w swoje możliwości przekraczania barier komunikacyjnych, społecznych, w sens terapii, rezygnuje lub odwraca się od osób, które chcą mu pomóc w powrocie do aktywności i partycypacji społecznej. Kto i jak może im pomóc, szczególnie w sytuacji, gdy podczas medycznej diagnozy osoby z afazją po udarze słyszymy słowa "to tylko ciało"? Wsparcia osobom o zróżnicowanych potrzebach komunikacyjnych i edukacyjnych powinni udzielać profesjonaliści, najczęściej są to pedagodzy specjalni, logopedzi. Czy pedagodzy specjalni są gotowi do dialogu bez słów?

Przywołane wydarzenia i poszukiwanie odpowiedzi na pytania wymaga interdyscyplinarnej refleksji, ale nie w perspektywie komunikacji medialnej, która jako część ludzkiego komunikowania się, powinna być przedmiotem rozważań medioznawców [Goban-Klas 2001]. Problem sposobów oddziaływania mass mediów na wizerunek osoby niepełnosprawnej i postrzeganie rzeczywistości społecznej $\mathrm{w}$ wymiarze integracji międzykulturowej jest również przedmiotem badań socjologów, antropologów, etyków, psychologów. Obserwacje własne i badania naukowe [Burger, za: Bartnikowska 2010, s. 36] potwierdzają tezę, że przekaz medialny odgrywa istotną rolę $\mathrm{w}$ akceptacji inności językowej grup mniejszościowych i tolerancji społeczno-kulturowej. Dlatego, jak zaznacza D. Podgórska-Jachnik [2013, s. 72] celowe jest kształtowanie wizerunku osoby z niepełnosprawnością „nasyconego treściami pozytywnymi”. Jednak przedmiotem rozważań niniejszego opracowania nie jest wizerunek osoby z niepełnosprawnością $\mathrm{w}$ dyskursie publicznym za pośrednictwem mediów, ale ustawiczne poszukiwanie różnorod- 
nych sposobów wsparcia osób w pokonywaniu ich trudności komunikacyjnych. Jedną z form pomocy jest stosowanie komunikacji alternatywnej.

W niniejszym artykule przedstawiono na podstawie przeglądu literatury główne założenia teoretyczne na temat komunikacji wspomagającej i alternatywnej z perspektywy pedagogiki specjalnej i logopedii. W drugiej części tekstu, na podstawie wyników z badań własnych, podjęto dyskusję o gotowości studentów, kierunku pedagogika specjalna, do stosowania w działaniach edukacyjno-terapeutycznych z osobami z zaburzeniami mowy i komunikacji różnorodnych form porozumiewania się bez słów.

\section{W poszukiwaniu słów i porozumiewania się bez słów - przegląd literatury}

Większość ludzi posługuje się w codziennej komunikacji systemem fonicznym. Jednak system znaków manualnych, opartych na gestach, układach rąk, palców, całego ciała lub w postaci piktogramów, był i nadal pozostaje narzędziem komunikacji w różnych sytuacjach, np.: gdy ludzie mówią różnymi językami dźwiękowymi i nie rozumieją co do nich mówimy, gdy nie słyszymy wypowiedzi słownej z dużej odległości albo w hałasie lub obowiązuje zakaz mówienia w określonej przestrzeni społeczno-kulturowej. System znaków słownych - fonicznych jest wtedy zastąpiony bezsłownym językiem, a znaki graficzne, symbole czy znaki manualne, np. gesty stają się substytutem mowy. Na co dzień mamy przykłady porozumiewania się bez słów. Jest to język gestów Indian lub komunikacja „milczących cystersów” albo sygnały follow, czyli marszałka (ang. marshaller), koordynatora ruchu na lotnisku. Gesty, systemy znaków, symboli pełnią istotną rolę w świecie ludzi, są jednak pomocnicze i drugoplanowe w stosunku do języka fonicznego.

M. Grochowalska [2001] na podstawie wniosków z badań własnych, twierdzi, że u dzieci w wieku przedszkolnym obserwuje się zależność miedzy wysokim poziomem rozwoju mowy a ilością i jakością używania gestów. W sytuacji, gdy osoba nie może mówić, pisać lub jej wypowiedzi są niezrozumiałe, język oparty na umownych symbolach, innych od przekazywanych za pomocą słowa, pisma, przejmuje funkcje mowy. Funkcja komunikacyjna systemu językowego obejmuje więc różne jej formy słowne i pozasłowne, ale najważniejszy jest pragmatyczny wymiar wypowiedzi, jej skuteczność i zrozumiałość w interakcji: odbiorca-nadawca.

Gesty i umowne znaki są z powodzeniem stosowane w terapii logopedycznej i praktyce edukacji specjalnej. Od lat 50. XX wieku nastąpił intensywny rozwój badań naukowych i praktyki w dziedzinie interdyscyplinarnej problematyki 
wspomagającej i alternatywnej komunikacji dla osób z zaburzeniami mowy i komunikacji. W 1983 roku założono Międzynarodowe Stowarzyszenie Komunikacji Wspomagającej i Alternatywnej [ISAAC] w Toronto, a skrót AAC [Augmentative and Alternative Communication] wpisał się w dyskurs o odmiennych od mowy sposobach porozumiewania się. Od ponad ćwierć wieku przyjmujemy, że komunikacja wspomagająca ma ułatwiać zdolność mówienia i zapewnić skuteczne porozumiewanie się, a komunikacja alternatywna „jest to proces przyswajania zastępczych sposobów dla zapewnienia substytutu braku mowy dźwiękowej" [Loebl 2008, s. 21].

Źródłem obecnego interdyscyplinarnego ujęcia AAC była praktyka surdopedagogiczna i działania surdologopedyczne wobec osób z niepełnosprawnością słuchową. Pierwsze wiadomości o próbach stosowania komunikacji wspomagającej $w$ wychowaniu i porozumiewaniu się z osobami niesłyszącymi pochodzą z XI-wiecznej Anglii. Z tego okresu zachowały się zestawy migów/gestów [Kirejczyk 1967]. Planowe i systematyczne stosowanie języka migowego, jako alternatywnej dla mowy formy komunikowania się i manualnej metody nauczania w szkole dla uczniów głuchych, wprowadził w XVIII-wiecznej Francji ks. M. de l'Épée. W Polsce pierwsze wzmianki o stosowaniu języka migowego w komunikacji i nauczaniu dzieci niesłyszących na bazie „Słownika mimicznego dla głuchoniemych i osób z nimi styczność mających" pochodzą z początku XIX wieku [Korzon 1998]. Należy przypomnieć, że w 1880 roku w Mediolanie, podczas Kongresu Nauczycieli Osób Głuchych, zakazano stosowania języka migowego w praktyce edukacyjno-terapeutycznej. Pod koniec XX wieku obserwujemy renesans komunikacji manualnej w kontaktach z osobami niesłyszącymi i zmiany w podejściu do teoretycznych założeń komunikacji, które stosuje się w surdopedagogice i surdologopedii. W Polsce dopiero początek XXI wieku przyniósł ustalenia legislacyjne $\mathrm{w}$ formie ustawy o języku migowym i innych środkach wspierających komunikowanie, obowiązującej od 1.02.2012 roku [Dz. U. z dnia 19 sierpnia 2011 r.] oraz interdyscyplinarne studia nad polskim językiem migowym [Czajkowska-Kisil 2000; Świdziński 2003; Tomaszewski 2004].

Sięganie do historii ma nam uświadomić, że początki AAC, wywodzące się z praktyki surdopedagogiki, mają kilkuwiekową tradycję, a współcześnie oprócz manualnych (migowych) systemów znaków, którymi posługują się osoby niesłyszące, stosuje się inne niewerbalne metody porozumiewania się: przestrzenno-dotykowe czy graficzne. Pierwszą formą ACC zastosowaną w Polsce $\mathrm{w}$ pracy z dziećmi z wieloraką niepełnosprawnością był system znaków graficznych Blissa. Były to lata 80. i 90. XX wieku, kiedy tworzono ośrodki edukacyjno-terapeutyczne.

Komu służy AAC, która umożliwia osobom ze zróżnicowanymi problemami w mówieniu realizację zamierzenia komunikacyjnego, wyzwala osobisty poten- 
cjał kreatywności językowej? AAC jest używana przez osoby, które od urodzenia lub wczesnego dzieciństwa mają trudności w kształtowaniu się mowy w sposób naturalny, np. osoby z niesłyszeniem prelingwalnym, z porażeniem mózgowym lub specyficznymi zaburzeniami mowy, a także osoby, które w biegu życia utraciły umiejętność mówienia, np. osoby z afazją, po usunięciu krtani.

Współcześnie J.J. Błeszyński [2016] w rozważaniach na temat istoty i pogranicza AAC zwraca uwagę na kilka ważnych zagadnień o charakterze edukacyjno-terapeutycznym. Po pierwsze, komunikacja wspomagająca i alternatywna nie jest odmiennym systemem porozumiewania się, tylko odmienną formą systemu językowego, który umożliwia przekaz lub odbiór informacji w interakcjach społecznych. Po drugie, podmiotowe i całościowe podejście do użytkowników AAC to dążenie do przekraczania granic komunikacyjnych $w$ rodzinie, przedszkolu, szkole, w celu motywacji do zróżnicowanych interakcji, a nie skupianie się na problemach wynikających z trudności przekazu - słownej wypowiedzi, co ogranicza, izoluje, a w konsekwencji wyklucza z partycypacji społecznej. Po trzecie, ujmowanie AAC jako specjalności interdyscyplinarnej, ukierunkowanej na logopedię. M. Zaorska [2015], poza kontekstami psychopedagogicznymi i logopedycznymi problematyki komunikacji osób z niepełnosprawnością, zauważa wymiar etyczny wyboru metod AAC. Odpowiedzialność i świadomość przy wyborze sposobu komunikacji dotyczy najczęściej rodziców i całej rodziny dziecka z niepełnosprawnością we współpracy ze specjalistami.

Powyższe rozważania są zbieżne z koncepcją interdyscyplinarnej logopedii, którą prezentuje V. Lechta [2011]. Twierdzi on, że podstawowym terminem logopedii jest zdolność komunikacyjna, personalnie zróżnicowana i/lub jej zaburzenia, w całej kompleksowości i wszystkich możliwych formach. Dlatego nie należy wobec osób posługujących się komunikacją alternatywną stosować określenia "Osoba z zaburzoną zdolnością komunikacyjną" [tamże, s. 20]. Jaki więc stosować termin w odniesieniu do osoby niesłyszącej posługującej się językiem migowym, jako jedną z form porozumiewania się, prawnie zatwierdzoną? Czy osoba ta ma zaburzoną zdolność komunikacyjną, czy tylko trudności w porozumiewaniu się fonicznym, za pomocą mówienia? W teorii i praktyce pedagogiczno-logopedycznej należy uwzględniać ocenę komunikującego się z otoczeniem dziecka, jako odbiorcy i nadawcy tekstu w zrozumiałej postaci, a pojęcie mowy i słownego porozumiewania uzupełnić o terminy: kompetencja językowa, sprawność komunikacyjna, zdolność komunikacyjna, kompetencja komunikacyjna [por. Grabias 2000]. Terminy te należy różnicować z zachowaniami konwerbalnymi. Termin zaburzone zachowanie konwerbalne wprowadził $i$ stosował w literaturze logopedycznej od lat 90. XX wieku, V. Lechta [1995]. Różnicowanie między zachowaniem konwerbalnym a komunikacją niewerbalną wymaga umiejętności diagnozowania tych zachowań, które utrudniają realizację zamierzenia komunikacyjnego, 
np. u osób jąkających się, niewidzących, osób z autyzmem, a także osób z niepełnosprawnością słuchową (grymasy i ruchy mimiczne na twarzy, poruszanie głową, kiwanie się, ruchy całego ciała). Niektóre dzieci stosują gesty idiosynkratyczne, które zastępują słowa, ale często nie są one właściwie rozumiane [Loebl 2008]. W tych sytuacjach komunikacyjnych istotną rolę odgrywa pedagog specjalny, a szkoła jest optymalnym miejscem do diagnozy, gdyż każdy uczeń w przestrzeni szkolnej, w kontaktach komunikacyjnych z nauczycielem, spędza kilkanaście lat życia, większość dni tygodnia - od poniedziałku do piątku. Jak zauważa K. Tersa [2014, s. 103] nauczyciel posiada bogatą "wiedzę na temat specyficznych uwarunkowań uczenia się" dziecka, w tym zróżnicowanych trudności komunikacyjnych. Wiedza nauczyciela o uczniu umożliwia $w$ na podstawie deskrypcji i wyjaśnienia problemów komunikacyjnych zaprojektować spersonalizowany program edukacyjno-terapeutyczny. Z kolei kultura wypowiedzi pedagoga i korzystanie z różnorodnych form komunikacji "pozwala na ocenę postaw wobec dziecka oraz efektywności podejmowanych przez nauczyciela działań" [Czaja-Chudyba, Muchacka 2016, s. 34].

Dla ustaleń diagnostycznych i opracowania kierunku terapii istotne jest również, w zależności od wielowymiarowości i fenomenu zaburzeń mowy, budowanie, usprawnianie realizacyjne lub odbudowywanie trzech, nawzajem się uzupełniających, kompetencji: językowej, komunikacyjnej i kulturowej, przy czym kompetencja kulturowa jest integralnym składnikiem kompetencji językowej [Grabias 2000]. Sygnowana wcześniej złożoność i symbolizm komunikacji ludzkiej wynika z faktu posługiwania się przez jej użytkowników szerokim spektrum symboli, gestów, zachowań, które są nośnikami znaczeń. M. Michalik [2013], odwołując się do interakcyjno-symbolicznego nurtu, podkreśla znaczenie interakcji w tworzeniu się jednostek i społeczności, w którym to procesie centralną rolę pełni człowiek i jego role społeczne. Dlatego reprezentanci lingwistyki stosowanej i psycholingwistyki stosują terminy: kompetencja językowa i kompetencja komunikacyjna [Grabias 2000]. Człowiek wraz z partycypacją społeczną w różnych przestrzeniach odczuwa potrzebę rozszerzania swoich kompetencji komunikacyjnych, co umożliwia podmiotowe kierowanie swoim życiem [Ferenz 2015].

Psycholingwiści [por. Kielar-Turska 1991; Kurcz 2000] zwracają również uwagę na interakcyjne przekazywanie dziecku doświadczeń. W praktyce oznacza to, że dziecko, ucząc się systemu językowego, w sposób naturalny „przechodzi od działania czy doświadczenia do słowa, a nie od słowa do doświadczenia. Dzieci nie tylko występują jako uczące się słów, ale jako producenci znaków" [Kielar-Turska 1991, s. 52]. Dziecko w okresie kształtowania się mowy tworzy w określonej interakcji wypowiedzi na bazie własnych reguł gramatycznych, co świadczy o twórczym i mądrym odtwarzaniu tego co wcześniej usłyszało i zarejestrowało w kontaktach komunikacyjnych. Chociaż wypowiedzi te mogą być nieprawidłowe, 
np. zakluczyć zamiast zamknąć, nie należy traktować ich w kategorii trudności komunikacyjnych czy błędów wymowy. Jest to przejaw zdolności komunikacyjnych.

Reasumując, we współczesnych interdyscyplinarnych rozważaniach o komunikacji ludzkiej nie jest już aktualna teza, że wypowiedź słowna jest jedynym środkiem porozumiewania się, a użycie metod komunikacji wspomagającej lub alternatywnej opóźnia rozwój języka mówionego dziecka. Założenie, że sposób porozumiewania się wykorzystywany przez dzieci z zaburzeniami rozwoju jest istotnie zróżnicowany, oznacza dostosowanie wypowiedzi do oczekiwań i zasobów słuchacza oraz warunków, w których przebiega interakcja komunikacyjna. Podstawową formą interakcji jest uczestnictwo w dialogu, a kształtowanie się i rozwój systemu językowego (kompetencji językowej) i zdobycie kompetencji komunikacyjnej pozostaje w relacji do specyficznych zdolności poznawczych. Jak zaznacza Z. Bauman [2012, s. 7] dialog wyklucza samotność, a krzewienie gotowości do dialogu wymaga wzajemnego zrozumienia, współpracy i solidarności, co podkreślają przedstawiciele nurtów współczesnej humanistyki, ale także nauk społecznych i o zdrowiu.

Prezentacja wybranych problemów porozumiewania się bez słów uświadamia nam zmiany na przestrzeni kilku wieków, a szczególnie ostatnich trzech dekadach, w podejściu do AAC jako sposobu komunikacji i metodzie kształcenia kompetencji komunikacyjnej. Problematyka komunikacji alternatywnej „mimo zgromadzonych doświadczeń (...) nadal wymaga doprecyzowania, reinterpretacji czy pełniejszego poznania na bazie umiejętnego łączenia doświadczeń praktyki i naukowej eksploracji" [Zaorska 2008, s. 13].

O znaczeniu komunikacji alternatywnej i wspomagającej w edukacji i terapii osób ze specjalnymi potrzebami komunikacyjnymi świadczy wyznaczenie w dniu 6 marca 2018 roku, przez organizację Europejskiego Komitetu Terapeutów [CPLOL, Standing Liaison Committee of Speech and Language Therapists / Logopedists in the European Union, http://www.cplol.eu/dostęp: 28.05.2017] przewodniego motywu: AAC. Od 2004 roku, utworzono i zainicjowano Europejski Dzień (przypada on zawsze 6 marca), w celu rozwijania świadomości społecznej na temat zaburzeń komunikacyjnych, ich wpływu na ludzkie zdrowie i jakość życia osób z zaburzeniami komunikacji oraz sposobów, aby im pomóc.

\section{Założenia badań własnych}

Ustalenia teoretyczne na temat roli porozumiewania się bez słów w życiu człowieka oraz wielowymiarowej, profesjonalnej pomocy osobom z niepełno- 
sprawnością, o zróżnicowanych potrzebach komunikacyjnych, były punktem wyjścia do badań własnych. Przyjęto następujące tezy:

1. Pomoc osobie $\mathrm{z}$ niepełnosprawnością $\mathrm{w}$ pokonywaniu barier komunikacyjnych wymaga od pedagoga specjalnego zrozumienia intencji drugiej osoby, zauważenia przekazu treści ukrytych, a nie tylko jawnych, to co chciano powiedzieć, a nie tylko to co zostało wypowiedziane [Macario, Rocchi 2011]. Dlatego $\mathrm{w}$ relacji pomagania osobie z niepełnosprawnością ważna jest gotowość pedagogów specjalnych do stosowania komunikacji alternatywnej lub wspomagającej, która ułatwia umiejętność słuchania i koncentracji na drugiej osobie w celu spostrzegania rzeczywistości i reagowania na nią.

2. W biegu życia każdy człowiek przygotowuje się do podjęcia zadań, jest gotowy „do działania jakościowo innego niż dotychczas” [Waloszek 2014, s. 9], a gotowość do wykonywania zadań pedagoga specjalnego trzeba wykształcić w toku kilkuletnich doświadczeń, które student nabywa w procesie studiowania. Zgodnie z omawianym zagadnieniem student pedagogiki specjalnej powinien być przygotowany do komunikacji alternatywnej i gotowy do jej stosowania w praktyce edukacyjno-terapeutycznej.

3. W podnoszeniu efektów i jakości kształcenia akademickiego ważne jest dbanie o język przyszłych nauczycieli, bo jest on odzwierciedleniem „zasobu interpretacji i wiedzy, na który nakładają się ich przekonania i wyobrażenia” [Czaja-Chudyba, Muchacka 2016, s. 34].

4. Przy określaniu kompetencji nauczyciela, z punktu widzenia współczesnej pedagogiki inkluzyjnej, uwzględnia się m.in. pomiar „samooceny posiadanych przez nauczyciela kompetencji, jak i oczekiwania wobec ich doskonalenia" [Byra, Kazanowski 2015, s. 258].

Celem prezentowanych badań było poznanie subiektywnej oceny studentów o roli komunikacji alternatywnej i wspomagającej w działaniach edukacyjno-terapeutycznych z osobą z niepełnosprawnością. Problemy badawcze sformułowano w postaci pytań:

1. Jaka jest gotowość studentów studiów wyższych licencjackich, przygotowywanych do zawodu pedagoga specjalnego, w zakresie wiedzy merytorycznej o komunikacji wspomagającej i alternatywnej jako odmiennej od mowy formy systemu językowego, która umożliwia przekaz lub odbiór informacji w interakcjach społecznych?

2. Jak studenci kierunku: pedagogika specjalna oceniają swoje umiejętności w zakresie znajomości i stosowania różnych, nowoczesnych form komunikacji alternatywnej lub wspomagającej i jakie podejmują działania $\mathrm{w}$ zakresie samodoskonalenia zawodowego umiejętności metodycznych w przekraczaniu granic komunikacyjnych? 
3. Jakie przekonania i subiektywny stosunek do podmiotowego i całościowego podejścia do użytkowników AAC prezentują badani studenci, w zależności o specjalności?

4. Czy i w jakim stopniu studenci są gotowi do krytycznej samooceny i chęci pogłębienia wiedzy oraz umiejętności w zakresie komunikacji alternatywnej? Badania przeprowadzono w roku akademickim 2016/2017 wśród 60 studentów z Uniwersytetu Pedagogicznego w Krakowie. Byli to studenci II roku studiów licencjackich, w systemie stacjonarnym i niestacjonarnym, kierunku: pedagogika specjalna, o zróżnicowanych specjalnościach:

- Edukacja i rehabilitacja uczniów niesłyszących i słabosłyszących (surdopedagogika),

- Edukacja i rehabilitacja uczniów z niepełnosprawnością intelektualną (oligofrenopedagogika),

- Terapia zajęciowa osób głębiej i głęboko niepełnosprawnych intelektualnie.

Badanymi były kobiety $(96,6 \%)$ i mężczyźni $(3,4 \%)$ w wieku od 20 do 24 lat. Najliczniejsza była grupa 20-22-latków (53 osoby, tj. 88,4\%). Dane na temat badanych osób ilustruje tabela 1.

Tabela 1. Badane osoby (liczba)

\begin{tabular}{|l|c|c|c|}
\hline \multirow{2}{*}{ Forma studiów } & \multicolumn{3}{|c|}{ Specjalność } \\
\cline { 2 - 4 } & surdopedagogika & oligofrenopedagogika & terapia zajęciowa \\
\hline Stacjonarne & 10 & 15 & 25 \\
Niestacjonarne & 10 & - & - \\
\hline Razem & 20 & 15 & 25 \\
\hline
\end{tabular}

Źródło: Badania własne.

Do zebrania materiału empirycznego zastosowano metodę sondażu diagnostycznego, a narzędziem badawczym był kwestionariusz ankiety własnego autorstwa. Zawierał on 35 pytań (zamkniętych, otwartych i półotwartych). Na podstawie odpowiedzi badanych ustalono gotowość studentów do posługiwania się systemem komunikacji alternatywnej $\mathrm{w}$ działaniach edukacyjno-terapeutycznych $\mathrm{z}$ osobą $\mathrm{z}$ niepełnosprawnością $\mathrm{w}$ trzech wymiarach: 1) wiedzy merytorycznej, 2) umiejętności metodycznych 3) przekonań w tym zakresie. Był to pomiar samooceny posiadanej gotowości (w zakresie wiedzy, umiejętności), do stosowania AAC przez studentów i subiektywne oczekiwania wobec doskonalenia się w tym zakresie. Wypełnianie ankiety trwało od 15 do 20 minut. 


\section{Wyniki z badań}

Porównując średnie wyniki uzyskane przez studentów można stwierdzić, że najwięcej badanych $(69,81 \%)$ cechuje pozytywny stosunek do użytkowników AAC oraz średni poziom wiedzy merytorycznej $(57,45 \%)$ i umiejętności jej stosowania $w$ działaniach edukacyjno-terapeutycznych $(58,75 \%)$. Dane na ten temat ilustruje zestawienie $\mathrm{w}$ formie tabeli 2 .

Tabela 2. Średnie wyniki badanych w trzech wymiarach gotowości, z podziałem na specjalności

\begin{tabular}{|l|c|c|c|c|c|}
\hline \multirow{2}{*}{ Wymiar gotowości } & \multicolumn{5}{|c|}{ Specjalność } \\
\cline { 2 - 6 } & $\begin{array}{c}\text { surdo- } \\
\text { pedagogika } \\
\text { (stacjonarne) }\end{array}$ & $\begin{array}{c}\text { surdo- } \\
\text { pedagogika } \\
\text { (niestacjo- } \\
\text { narne) }\end{array}$ & $\begin{array}{c}\text { oligofreno- } \\
\text { pedagogika } \\
\text { (stacjonarne) }\end{array}$ & $\begin{array}{c}\text { terapia } \\
\text { zajęciowa } \\
\text { (stacjonarne) }\end{array}$ & $\bar{x}$ \\
\hline Wiedza & 60,0 & 45,5 & 61,86 & 56,2 & 57,45 \\
\hline Umiejętności & 70,0 & 62,0 & 52,00 & 51,0 & 58,75 \\
\hline Przekonania & 74,0 & 69,0 & 70,66 & 65,6 & 69,81 \\
\hline $\bar{x}$ & 69,66 & 61,33 & 65,33 & 60,33 & - \\
\hline
\end{tabular}

Źródło: Badania własne

Średnie wyniki gotowości studentów do stosowania komunikacji alternatywnej lub wspomagającej w działaniach edukacyjno-terapeutycznych są zróżnicowane w zależności od specjalności. Najwyższe wskaźniki procentowe uzyskali studenci studiów stacjonarnych - nauczycielskich o specjalności: edukacja i rehabilitacja uczniów niesłyszących i słabosłyszących (surdopedagogika - 69,66\%) i edukacja i rehabilitacja uczniów z niepełnosprawnością intelektualną (oligofrenopedagogika-65,33\%). Niższe średnie wskaźniki gotowości w zakresie przekraczania granic komunikacyjnych z osobami niepełnosprawnymi otrzymali studenci studiów niestacjonarnych o specjalności surdopedagogika (61,33\% osób) oraz grupa, która wybrała specjalność nienauczycielską: terapia zajęciowa osób głębiej i głęboko niepełnosprawnych intelektualnie (60,33\% osób).

Analiza danych, na podstawie których określono subiektywny stosunek studentów do podmiotowego i całościowego podejścia do użytkowników AAC, wykazała, że większość badanych $(86,6 \%)$ zdecydowanie popiera możliwość jej stosowania $\mathrm{w}$ edukacji i rehabilitacji osób niemówiących, przy założeniu, że zarówno pedagog specjalny, jak i rodzice dzieci niepełnosprawnych powinni posługiwać się systemem językowym preferowanym przez ucznia/dziecko. Stosowanie AAC w codziennej pracy może być dla 11,6\% przyszłych pedagogów 
specjalnych uciążliwe, szczególnie dla grupy osób, które uzyskały niższe od średniej wskaźniki w samoocenie swojego stosunku emocjonalnego do AAC (studenci o specjalności terapia zajęciowa $-65,6 \%$ i surdopedagogika - 69\%, w trybie studiów niestacjonarnych).

Zadowalającym wskaźnikiem pozytywnego postrzegania AAC jako wartości, jest deklaracja 63\% studentów (w większości studiów stacjonarnych nauczycielskich o specjalności surdopedagogika i oligofrenopedagogika), w tym dla 15\% z nich jest to zdecydowana wartość, przyjęta w subiektywnej hierarchii zasad, przekonań i norm etycznych. Również dwu- i wielojęzyczność jest dla młodego pokolenia, w większości 20-22-latków, wysoko ocenianą umiejętnością. Dla 3/4 studentów znajomość dwu lub więcej języków jest standardem i wymogiem dla umiejętności człowieka XXI weku. Deklaracja wysokiej oceny AAC w subiektywnej hierarchii wartości nie oznacza akceptacji ustawowego prawa do różnych sposobów komunikacji. Połowa studentów nie ma zdania na temat obowiązującego $\mathrm{w}$ tym zakresie przestrzegania prawa ustawowego.

Zgodnie z planem studiów obowiązującym na kierunku: pedagogika specjalna UP w Krakowie, w ramach zajęć dydaktycznych obligatoryjnych na pierwszym roku, są obowiązkowe kursy z języka migowego, w wymiarze 30 godzin w semestrze pierwszym (poziom A) i 30 godzin w semestrze drugim (poziom B). Za pozytywne zaliczenie kursu student łącznie otrzymuje 4 punkty ECTS [plany i programy studiów IPS, http://www.ips.up.krakow.pl, dostęp: 28.05.2017]. Jak studenci oceniają swoje umiejętności w zakresie stosowania języka migowego jako jednej z form ACC? Biorąc pod uwagę samoocenę umiejętności, stwierdzono, że najwyżej określili swoje przygotowanie praktyczne. studenci o specjalności surdopedagogika ( $w$ trybie stacjonarnym i niestacjonarnym, odpowiednio $70 \%$ i $62 \%$ osób). Należy zaznaczyć, że 80\% wszystkich badanych deklarowała znajomość AAC w zakresie stosowania języka migowego, ale osoby te w większości oceniły tę umiejętność na niezadowalającym i niskim poziomie (65\%). Połowa studentów, która wiąże swój przyszły zawód z edukacją i rehabilitacją uczniów z niepełnosprawnością intelektualną $\mathrm{w}$ różnym stopniu, oceniła swoje umiejętności na niskim i średnim poziomie, a znajomość języka migowego zadeklarowało 22,5\% tej grupy studentów. Ponad połowa wszystkich badanych $(61,6 \%)$ podejmowała wysiłki, by uczestniczyć $w$ rozmowach przy użyciu AAC.

Dalsza analiza zestawienia wyników wykazała, że podstawowa wiedza na temat ACC jest zróżnicowana - od poziomu wysokiego do średniego. Najwięcej studentów, o specjalności oligofrenopedagogika $(61,86 \%)$ i surdopedagogika (60\%) w systemie studiów stacjonarnych, wykazało się wysokim poziomem wiedzy o AAC, a niższą wiedzę uzyskali studenci o specjalności nienauczycielskiej: terapia zajęciowa i studenci surdopedagogiki w trybie studiów niestacjonarnych. 
Stwierdzono, że studenci nie posiadają dostatecznej wiedzy na temat: określenia wczesnych wskaźników ryzyka zagrożeń rozwoju mowy i komunikacji w pierwszym roku życia dziecka, zdefiniowania istoty wielomodalnego przekazu komunikatu. Najwięcej nieprawidłowych odpowiedzi odnotowano przy określeniu systemu znaków, które możemy stosować w AAC.

Reasumując, osoby, które są przygotowywane do zawodu pedagoga specjalnego, pozytywnie percypują alternatywne lub/i wspomagające formy porozumiewania się jako jedna $\mathrm{z}$ form wspierania skutecznego porozumiewania się ludzi, ale równocześnie osoby te zdają sobie sprawę z niskiego poziomu umiejętności w tym zakresie. Grupa studentów, która krytycznie oceniła swoje umiejętności w zakresie AAC, bardzo rzadko podejmuje działania w samodoskonaleniu umiejętności językowych, w wybranym przez siebie systemie porozumiewania się bez słów. Stanowią oni 15\% wszystkich badanych.

Średni poziom wiedzy merytorycznej studentów na temat komunikacji wspomagającej i alternatywnej, jako odmiennej od mowy formy systemu językowego, wymaga (szczególnie na studiach niestacjonarnych) intensywnej pracy ze strony studenta, jak i nauczyciela akademickiego w osiąganiu rzeczywistych efektów kształcenia.

Wiedza i umiejętności, które są integralnym wymiarem gotowości studenta studiów licencjackich do działań edukacyjno-terapeutycznych z osobą niepełnosprawną w przekraczaniu granic komunikacyjnych, nie zawsze są odzwierciedleniem przekonań i wyobrażeń o przyszłej pracy zawodowej oraz akceptacji aktów prawnych o charakterze ogólnym, ale powszechnie obowiązującym.

W świetle przedstawionych wyników z sondażu diagnostycznego wynika, że trudno mówić o sylwetce absolwenta studiów wyższych, uzyskiwanych kwalifikacjach oraz uprawnieniach zawodowych bez refleksji na temat subiektywnej oceny studenta $\mathrm{w}$ przygotowaniu do pełnienia zadań pedagoga specjalnego, w tym do działań edukacyjno-terapeutycznych w zakresie kształtowania kompetencji komunikacyjnych dzięki komunikacji alternatywnej i wspomagającej. Dlatego zaliczenie zajęć to nie tylko pozytywna ocena z kolokwium, egzaminu (zgodna z przelicznikiem punktów ECTS), ale również subiektywna, rzetelna autoewaluacja/samoocena wiedzy, umiejętności i kompetencji społecznych, jako wskaźnika rzeczywistych, a nie pozornych osiągnięć kierunkowych efektów kształcenia, zgodnych z polską ramą kwalifikacji. Wymaga to jednak współodpowiedzialności i partnerstwa edukacyjnego, w relacji: student-nauczyciel akademicki. 


\section{Zakończenie}

Obserwowane na przestrzeni ostatnich trzech dekad dynamiczne przemiany $\mathrm{w}$ postrzeganiu opieki, kształcenia i terapii dzieci i młodzieży z niepełnosprawnością w biegu ich życia, zmierzały do wsparcia w przezwyciężaniu trudności w spełnianiu wymagań społecznych o charakterze partnerskiej integracji, uczestnictwa i aktywności w grupie społecznej, nie tylko wspólnoty osób komunikujących się mową, ale również alternatywnymi sposobami. W efekcie opracowano takie formy i metody pomocy, które wymagają od pedagogów specjalnych przekraczania granic komunikacyjnych nie tylko na podstawie wiedzy o wielowymiarowości fenomenu trudności lub zaburzeń mowy i komunikacji, ale również dzięki przekonaniom o potrzebie poszukiwania wspólnego systemu językowego, innego od przyjętych przez większość ludzi oraz ustawicznego doskonalenia umiejętności w tym zakresie.

Zgodnie z europejskimi tendencjami rozwijania świadomości społecznej na temat deprecjacji i wykluczenia osób z zaburzeniami mowy i komunikacji należy promować tezę, że wyznacznikiem współczesnego pedagoga specjalnego, określonego w charakterystyce sylwetki absolwenta studiów wyższych, winna być znajomość kilku systemów językowych, np. języka narodowego i języka angielskiego oraz języka komunikacji alternatywnej lub wspomagającej, jako atrybutu na rynku pracy i w zróżnicowanym kulturowo świecie.

\section{Bibliografia}

Bartnikowska U. (2010), Głuchota - mniejszość językowa, kulturowa, pogranicze..., czyli społeczny kontekst badania zjawisk zwiazanych z uszkodzeniem słuchu, „Niepełnosprawność. Półrocznik Naukowy", nr 4, s. 27-41.

Bauman Z. (2012), To nie jest dziennik, Wydawnictwo Literackie, Kraków.

Błeszyński J.J. (2016), Istota i pogranicza komunikacji alternatywnej i wspomagającej [w:] Edukacyjne oblicza komunikacji - dyskurs interdyscyplinarny, J.J. Błeszyński, K.B. Kochan, E.M. Skorek (red.), Uniwersytet Zielonogórski, Zielona Góra.

Byra S., Kazanowski Z. (2015), Postrzeganie kompetencji zawodowych nauczyciela w edukacji inkluzyjnej - próba pomiaru [w:] W poszukiwaniu indywidualnych dróg wspierających wszechstronny rozwój osób z niepetnosprawnościq, B. Szczupał, A. Giryński, G. Szumski (red.), Wydawnictwo APS, Warszawa.

Czaja Chudyba I., Muchacka B. (2016), Nauczyciele wczesnej edukacji. Koncepcje, ksztatcenie, wyzwania, Wydawnictwo PETRUS, Kraków.

Czajkowska-Kisil M.(2000), Język migowy jako przedmiot nauczania, „Audiofonologia”, nr 16, s. 135-143.

Ferenz K. (2015), Przedmowa [w:] Dzieci o specjalnych potrzebach edukacyjnych. Diagnoza - edukacja - terapia, B. Wilczura (red.), Oficyna Wydawnicza „Impuls”, Kraków. 
Gazur Ł. (2016), Tak, to byt Krzysztof. On tam byt. Powroty! Drugie narodziny aktora, „Dziennik polski", nr 287 z 9 grudnia, s. C04.

Goban-Klas T. (2001), Media i komunikowanie medialne, PWN, Warszawa.

Grabias S. (2000), Mowa i jej zaburzenia, „Logopedia” t. 28, s. 7-36.

Grochowalska M. (2001), Umiejętności komunikacyjne ucznia i nauczyciela [w:] Nauczyciel i uczeń w edukacji zintegrowanej w klasach I-III, I. Adamek (red.), Wydawnictwo Naukowe AP, Kraków.

Gunia G. (2011), Komunikacja alternatywna [w:] Wprowadzenie do logopedii, G. Gunia, V. Lechta (red.), Oficyna Wydawnicza „Impuls”, Kraków.

http://www.ips.up.krakow.pl [dostęp: 20.04.2017].

http://www.cplol.eu/ [dostęp: 28.05.2017].

Kielar-Turska M. (1991), O potrzebie nowego podejścia do przedmiotu logopedii [w:] Przedmiot logopedii. Seria: Komunikacja językowa i jej zaburzenia 1, UMCS, Lublin.

Kirejczyk K. (1967), Ewolucja kształcenia dzieci głuchych, Nasza Księgarnia, Warszawa.

Korzon A. (1998), Totalna komunikacja jako podejście wspomagające rozwój zdolności językowych uczniów głuchych, Wydawnictwo Naukowe WSP, Kraków.

Kurcz I. (2000), Psychologia języka i komunikacji, Wydawnictwo Naukowe Scholar, Warszawa.

Lechta V. (1995), Zaburzenia komunikacji konwerbalnej i ich znaczenie w logopedii, „Logopedia”, nr 22, s. 95-98.

Lechta V. (2011), Podstawy teoretyczne logopedii [w:] Wprowadzenie do logopedii, G. Gunia, V. Lechta (red.), Oficyna Wydawnicza „Impuls”, Kraków.

Loebl W, (2008), Szkic rozwoju wspomagającej i alternatywnej komunikacji w Polsce [w:] Alternatywne i wspomagajace metody komunikacji, red. J.J. Błeszyński, Oficyna Wydawnicza „Impuls", Kraków.

Macario L., Rocchi M. (2011, Komunikacja w relacjach niesienia pomocy, Wydawnictwo WAM, Kraków.

Michalik M. (2013), Teoria logopedii jako interakcja. Między interakcjonizmem symbolicznym a lingwistyka mentalna, "Nowa Logopedia”, t. 4, s. 13-32, Collegium Columbinum Kraków, http://hatesz.vot.pl/logopedia/assets/uploads/30ba13770bac8d077675e05d4528ba4cc062 d4c2.pdf [dostęp: 28.05.2017].

Podgórska-Jachnik D. (2013), Deprecjacja osób z niepetnosprawnościq w dyskursie publicznym za pośrednictwem mediów [w:] Człowiek z niepetnosprawnością w rezerwacie przestrzeni publicznej, Z. Gajdzika (red.), Oficyna Wydawnicza „Impuls”, Kraków.

Świdziński M., Gałkowski T. red. (2003), Studia nad kompetencja językowa i komunikacyjna niestyszących, Warszawa.

Tersa K. (2014), Kompetencje diagnostyczne nauczycieli. Oczekiwania i wyzwania, „Niepełnosprawność. Dyskursy Pedagogiki Specjalnej", nr 16, s. 90-105.

Tomaszewski P. (2004), Polski język migowy - mity ifakty , „Poradnik Językowy”, nr 6, s. 59-72.

Waloszek D. (2014), Między przedszkolem a szkoła. Rozważania o gotowości dzieci do podjęcia nauki w szkole, Wydawnictwo Akademickie "Żak".

Zaorska M. (2008), Z recenzji [w:] Alternatywne i wspomagające metody komunikacji, J.J. Błeszyński (red.), Oficyna Wydawnicza „Impuls”, Kraków.

Zaorska M. (2015). Wprowadzanie metody/metod komunikacji alternatywnej - konteksty psychopedagogiczne i etyczne, „Niepełnosprawność. Dyskursy Pedagogiki Specjalnej”, nr 20, s. 155-164. 